\title{
Potential Use of $I$. suffruticosa in Treatment of Tuberculosis with Immune System Activation
}

\author{
Camila Bernardes de Andrade Carli ${ }^{1}$, Marcela Bassi Quilles ${ }^{1}$, \\ Danielle Cardoso Geraldo Maia ${ }^{1}$, Clarice Q. Fujimura Leite ${ }^{1}$, \\ Wagner Vilegas ${ }^{2}$ and Iracilda Z. Carlos ${ }^{1}$ \\ ${ }^{1}$ Departamento de Análises Clínicas e Departamento de Ciências, Unesp, \\ R. Expedicionários do Brasil 1601, Araraquara, SP, \\ ${ }^{2}$ Departamento de Ciências Biológicas, Unesp, \\ Rodovia Araraquara-Jaú, Araraquara, SP, \\ ${ }^{3}$ Departamento de Química Orgânica, Unesp, \\ R. Prof. Francisco Degni, Araraquara, SP, \\ Brazil
}

\section{Introduction}

\subsection{Tuberculosis and immune system}

Mycobacterium tuberculosis is a serious threat to humankind, with over 8 million cases of tuberculosis (TB) annually, killing almost 3 millions of people per year around the world (WHO, 2008). Moreover, side effects from first-line anti-TB drugs can cause significant morbidity, and compromise treatment regimens for TB (Yee et al., 2003). Most healthy individuals are able to control TB infection with a vigorous immune response, halting the progression of the disease, but not necessarily eradicating the microorganism (McKinney, 2000).

The bacterium resides within macrophages, allowing them to resist the antimicrobial effector mechanisms of the host (Raupach \& Kaufmann 2001). Macrophages constitute one of the main phagocyte cells of the immunological system and they are the first cells involved in an immunological response. Part of their effectiveness is due to the production of nitric oxide (NO), hydrogen peroxide $\left(\mathrm{H}_{2} \mathrm{O}_{2}\right)$ and cytokines, as well as phagocytosis of strange particles (Allavena et al., 2008; Carlos et al., 2004; Keil, 1999). Thus, the elimination of tuberculosis bacillus is involved in the production of these effectors molecules from immune system.

The hydrogen peroxide, generated by macrophages in a reaction catalyzed by an NADPH oxidase, was the first identified effector molecule that mediated mycobacteriocidal effects of mononuclear phagocytes (Lopes et al., 2005; Walker \& Lowrie, 1981). In spite of several studies have indicated significant $M$. tuberculosis resistance to oxidative stress in vitro and in vivo, a recent study showed that $\mathrm{H}_{2} \mathrm{O}_{2}$ induced the complete sterilization of the cultures of M. tuberculosis by $24 \mathrm{~h}$, after the exposition to $50 \mathrm{mM}$ of $\mathrm{H}_{2} \mathrm{O}_{2}$ (Volskuill et al., 2011). 
NO formed by the action of the inducible form of nitric oxide synthase (iNOS) reacts with oxygen radical forming RNI. NO and related RNI have been reported to possess antimycobacterial activity (Chan et al., 2004; Kwon, 1997). Although the role of NO in human tuberculosis remains unsettled evidence supporting its importance has come from a variety of areas (Nathan \& Shiloh, 2000) including the demonstration that human granulomas contain iNOS, endothelial-NOS and nitrotyrosine, a compound whose accumulation indicates production of NO (Nathan, 2002). Additionally, the ability of human alveolar macrophages to kill $M$. tuberculosis is dependent on the activity of iNOS and the human macrophages taken from healthy subjects latently infected with $M$. tuberculosis produce NO controlling the growth of the bacteria (Yang et al., 2009). The presence of NO within human granulomas could contribute to host resistance since in vitro experiments demonstrate direct RNS-mediated bacteriostatic (Firmani \& Riley, 2002; Ouellet et al., 2002; Voskuil et al., 2003) and bactericidal activity (Nathan, 2002). Mice deficient in both phox and $i N O S$ are much more susceptible to $M$. tuberculosis infection than either mutant alone which would indicate that RNS and ROS protect the host in a partially redundant fashion (Shiloh \& Nathan, 2000; Volskuill et al., 2011).

TNF- $\alpha$ is a cytokine that plays multiple roles in immune and pathologic responses in tuberculosis, also required for acute infection control (Babbar et al., 2006; Flynn et al., 1995; Palladino et al., 2003). The pro-inflammatory cytokine TNF-a produced by activated macrophages is a central contributor to the immune response against M. tuberculosis (Flynn, 1986; Marino et al., 2007 ). The role of TNF is of clinical interest due to the association of anti-inflammatory TNF-a blocking drugs with reactivation of latent TB in humans (Keane et al., 2001; Wintrop,2006). This cytokine has multiple immunological functions during infection with $M$. tuberculosis: It has a direct role in immune cell recruitment via upregulation of endothelial adhesion molecules (Zhou, et al., 2007) facilitating transendothelial migration of immune cells to the site of infection. TNF-a regulates production of chemokines by macrophages (Algood et al., 2006; Roach et al., 2002); chemokines can further induce transendothelial migration and coordinate recruitment of immune cells within the tissues. TNF- $\alpha$ activates macrophages in conjunction with the cytokine IFN-ץ (Flesch \& Kaufmann 1986; Roock et al., 1986; Carlos et al., 2009) such activated macrophages can kill intracellular mycobacteria. TNF-a can also induce necrotic or apoptotic cell death in macrophages (Laster et al., 1988) that is promoted by TB infection (Keane, et al., 2001).

\subsection{Plant with antimycobacterial and immunostimulating activity}

With proposal to stimulate the immune system, some plants can be used in collaboration with the standards drugs for the treatment of tuberculosis. Moreover, there are a lot of plants that can be able to presenting an antimycobacterial activity.

It is possible to assign this effect to the substances contained in its structure which are responsible for protecting the plant structure from aggressive agents in what concerns the active ingredients of plants with an antimicrobial character. Most of these substances are part of the secondary metabolites which consist of substances produced by plants which are not vital and involved in metabolic mechanisms. Flavonoids, tannins, terpenes, alkaloids, phenolic compounds, etc are examples of secondary metabolites. Thereby, many of these compounds protect the vegetal structure against external aggression such as insects, solar radiation, fungi, bacteria and viruses (Heldt, 1997). 
Terpenoids are known as natural insecticides. This class also includes limonoids, limonene and myrcene which plays an important role in the protection of the plants against insects. Some terpenoids have already been tested and have manifested an activity against mycobacterium (Cantrell et al., 2001). Terpenes are composed by basic units of active isoprene isopentenilpirofosfatou, and originate triterpenes and sesquiterpenes previously mentioned in literature as substances with bacterial features (Januario et al., 2002; Pietro et al., 2000).

Essential oils such as geraniol, citronellol, cineole and other genus Eucalyptus L'Herit, are recognized as bactericide (Hinou et al. 1989; Leite et al., 1998). The alkaloid obtained from extracts of leaves of $A$. Vasic, vasicine acetate and 2-acetyl benzyl amine showed promising antimycobacterial activities in several strains of M. tuberculosis (Gupta et al., 2010).

The endophytic fungi are microorganisms capable of producing potentially bioactive metabolites. These molecules may have hormonal, antibiotic or antitumor activities and other biological functions of enormous industrial and biotechnology interest. Tan and Zou (2001) examined the diversity of metabolites from isolated endophytic fungi and reported the isolation of substances belonging to different structural groups such as steroids, xanthones, phenols, isocoumarins, alkaloids, quinones, furandionas, terpenoids, peptides, cytochalasins and aliphatic compounds. 3-D citosporona, fomopsolida and the acid "coletótricose" stand out for their antibacterial activity shown in several studies (Brady et al. 2000; Zou et al., 2000).

Considering the importance of immunomodulation in the treatment of tuberculosis, the activation of some components of the immune system is a great advantage when it is associated with the bacterial/bacteriostatic activity of the plants. As examples of substances which have immunostimulant and antimicrobial actvities associated, the lectin derived from Synadenium carinatum has an important stimulatory activity of granulocytes and NK cells. It is also able to stimulate the expression of TNF- $\alpha$, IL-1 $\beta$ and iNOS in murine peritoneal macrophages (Cardoso, 2006). This activity is due, partially, to the presence of tannins. This class of secondary metabolites can stimulate the production of IL-1 $\beta$ and TNF- $\alpha$ in macrophages as well as having a significant antimicrobial activity with MIC $<100 \mu \mathrm{g} / \mathrm{mL}$ against M. tuberculosis (Lawal et al., 2011; Miyamoto et al. 1993).

Scutellaria baicalensis has also an immunostimulant action combined with antibacterial activity. In addition to the activity against M. tuberculosis, S. baicalensis employs a toxic activity against cholera, typhoid, streptococcus, E. coli, Pneumococcus, Klebsiella pneumoniae, Proteus vulgaris Mycobacterium tuberculosis, Pseudomonas aeruginosa and Corynebacterium diphtheria. This plant induces the production of TNF-a possibly due to the effect of flavonoid wogonin (Chang et al. 1986; Franzblav \& Cross 1986; Huang, 1993; Jen et al., 2002). This mediator was also investigated as TNF-a acts in the production of nitric oxide. The results showed that low concentrations of wogonin induce the production of nitric oxide and high concentrations inhibit the production (Jen et al., 2002).

Similarly, Glycyrrhiza glabra evinced antimicrobacterial activity in the concentration of $0.5 \mathrm{mg} / \mathrm{mL}$. After a phytochemical analysis, the tuberculosis which is toxic to the bacilli at concentrations of $0.029 \mathrm{mg} / \mathrm{mL}$ (Gupta et al., 2008) was attributed to the activity against $M$. glabridin. Regarding the immunomodulatory activity, it has been observed that the extract of Glycyrrhiza glabra intensely activated granulocytes and NK cells (Cheell et al., 2010). 
Our research group studied Indigofera suffruticosa Miller (Fabacesae) with the aim to collaborate with the discovery of alternatives treatments for tuberculosis. Since at this moment there is no new drug generation able to eliminate the bacillus and simultaneously stimulate the immune system we investigated the antimycobacterial and immunological activity of methanol (METH) and dichloromethane (DCM) extracts of I. suffruticosa.

I. suffruticosa is found in tropical and subtropical areas and is well adapted to growth in semi-arid regions and soils of low fertility (Paiva, 1987). A chemical investigation of extracts of leaves of I. suffruticosa in Natural Products Alert (NAPRALERT) and Chemical Abstracts databases has revealed the presence of alkaloids, flavanoids, steroids, proteins, carbohydrates and indigo. Some recent reports have demonstrated the in vitro bioassay activity of plant-derived terpenoids against M. tuberculosis (Cantrell et al., 2001; Higuchi et al., 2008). The literature also reports the antimycobacterial activity of many classes of natural products: such as alkanes, phenolics, acetogenic quinines, flavonoids, triterpenes, flavonones and chalcones (Copp, 2003; Higuchi et al., 2008; Pavan et al., 2009). Previous results demonstrated that indigotin alkaloid can enhance macrophage functions and therefore contribute to the host defense against pathogens and tumors (Lopes et al., 2006).

\section{Materials and methods}

\subsection{Plant material and samples}

Aerial parts of I. suffruticosa were collected in Rubião Junior, Botucatu city, São Paulo State, Brazil, and identified by Prof. Dr. Jorge Yoshio Tamashiro. The immunological assays were performed as soon as the plant was collected. A voucher specimen (HUEC 129598) was deposited at the Herbarium of the Universidade Estadual de Campinas (Unicamp), Campinas, SP, Brazil. Aerial parts of I. suffruticosa $(1.1 \mathrm{Kg})$ were dried Activity of the I. suffruticosa $\left(40^{\circ} \mathrm{C}\right)$, powdered and extracted exhaustively at room temperature with dichloromethane and methanol, successively. Solvents were evaporated at $40^{\circ} \mathrm{C}$ under reduced pressure to afford the DCM (15.2 g) and METH (30.0 g) extracts. Each extract was first solubilized in dimethyl sulfoxide (DMSO) and then diluted in an appropriated culture medium, RPMI-1640 for the immunological assays and Middlebrook 7H9 for the determination of antimycobacterial activity $(62.5-4000 \mu \mathrm{g} / \mathrm{mL})$.

\subsection{Peritoneal macrophages}

Peritoneal macrophages Thioglycollate-elicited PEC were harvested from Swiss mice using $5.0 \mathrm{~mL}$ of sterile PBS, pH 7.4. The cells were washed twice by centrifugation at $200 \mathrm{~g}$ for 5 min at $4^{\circ} \mathrm{C}$ and re-suspended in RPMI-1640 medium (Sigma). The adherent cells were obtained by incubation for $1 \mathrm{~h}$ at $37^{\circ} \mathrm{C}$ in an atmosphere of air/CO2 (95:5, v/v) (Forma Scientific) and, incubated with LPS or RPMI-1640 medium. This protocol was in agree with the regulations of Research Ethics Committee (\# 01/2005).

\subsection{MTT assay for cell viability}

PEC (5x106 cells/mL) was re-suspended in RPMI- 1640 medium. The suspension $(100 \mu \mathrm{L})$ and the extracts $(100 \mu \mathrm{L})$ were added to each well of a 96-well tissue culture plate and they were incubated for $24 \mathrm{~h}$. The 3-(4,5-dimethylthiazol-2-yl)-2,5-diphenyl-tetrazolium bromide 
(MTT) colorimetric assay was performed as described by Mosmann (1983) . Only cells and culture medium (RPMI- 1640) were used as a control that corresponds to $100 \%$ of macrophages viability.

\subsection{Measurement of $\mathrm{H}_{2} \mathrm{O}_{2}$ production}

Hydrogen peroxide measurement the adherent cells of PEC $\left(2 \times 10^{6} \mathrm{cells} / \mathrm{mL}\right)$ was measured using the horseradish peroxidase-dependent phenol red oxidation microassay (Pick \& Mizel, 1981). Phorbol myristate acetate (PMA, Sigma, St. Louis, MO) were used as a positive control.

\subsection{Measurement of NO production}

NO measurement the adherent cells of PEC $\left(5 \times 10^{6} \mathrm{cells} / \mathrm{mL}\right)$ was mensured using Griess reagent (Green et al., 1982). E. coli O111B lipopolysaccharide (LPS - $1 \mu \mathrm{g} / \mathrm{mL}$ ) solution were used as positive control.

\subsection{Measurement of TNF- $\alpha$ production}

The determination of TNF-a in the supernatants was based in its property to destroy L929 tumoral cell line (mouse tumour fibroblast) Carlos et al. (1994). LPS $(1 \mu \mathrm{g} / \mathrm{mL})$ was used as a positive control.

\subsection{Determination of antimycobacterial activity by MABA}

The minimum inhibitory concentration (MIC) of DECE was determined against $M$. tuberculosis H37Rv (American Type Culture Collection 27294) in Middlebrook 7H9 medium using the Microplate Alamar Blue Assay - MABA (Collins \& Franzblau, 1997). For standard test, the MIC value of Isoniazid (Sigma) was determined each time. The acceptable MIC of Isoniazid ranged from 0.015 to $0.05 \mu \mathrm{g} / \mathrm{mL}$.

\subsection{Statistical analysis}

The results are expressed as means \pm SD of five experiments. One-way ANOVA with Dunnett's post test was performed using GraphPad InStat (San Diego, California, US) with the level of significance set at $\mathrm{p}<0.05$.

\section{Results and discussion}

Actually, TB multiple drug resistance has become a major threat worldwide and thus calls for an urgent search for new and effective treatments for this deadly disease. Naturally occurring compounds as extracts from plants have indicated that inhibitory activity against M. tuberculosis is widespread in nature (Okunade et al., 2004).

The cytotoxicity effect of the extract was evaluated by the determination of MTT (a tetrazolium salt: 3-(4,5-dimethylthiazol-2-yl)-2,5-diphenyl tetrazolium bromide) (Mosmann, 1983) (Table 1). The index of cytotoxicity 50 (IC 50$)$ found was in the concentration of $200 \mu \mathrm{g} / \mathrm{mL}$. 


\begin{tabular}{|l|l|}
\hline Extracts & Viability (\%) \\
\hline Control & $100 \pm 0,00$ \\
\hline $600^{a}$ & $15,73 \pm 1,90$ \\
$400^{a}$ & $30,29 \pm 4,32$ \\
$200^{a}$ & $55,29 \pm 1,36$ \\
$100^{a}$ & $71,57 \pm 1,82$ \\
\hline
\end{tabular}

Table 1. Effect of methanolic and dichloromethane extracts of Indigofera suffruticosa on the viability of peritoneal macrophages. ${ }^{\mathrm{a}} \mu \mathrm{g} / \mathrm{mL}$

This study evaluated the antimycobacterial activity the extracts of I. suffruticosa and its action in innate immune system. The antimycobacterial activity of METH and DCM is presented in table 2. Gu et al. (2004) considered active plant extracts with MIC value $\leq 128$ $\mu \mathrm{g} / \mathrm{mL}$. Thus we considered a promising result the MIC of $125 \mu \mathrm{g} / \mathrm{mL}$ found in METH crude extract.

\begin{tabular}{|l|c|c|c|}
\hline & Methanolic & Dichloromethane & Isoniazida \\
\hline MIC & $125^{\mathrm{b}}$ & $1000^{\mathrm{b}}$ & $0,05^{\mathrm{b}}$ \\
\hline
\end{tabular}

Table 2. Minimal inhibitory concentration (MIC) in presence of methanolic and dichloromethane extracts of the plant Indogofera suffruticosa. aStandard drug, ${ }^{\mathrm{b}} \mu \mathrm{g} / \mathrm{mL}$.

The extracts presented a high production of nitric oxide with statistically significant values compared to the negative control $(\mathrm{p}<0,001)$. The amount of NO produced by the METH extract $\left(105,99 \mu \mathrm{mol} / 5.10^{5}\right.$ cells) was larger than the production of DCM extract $(58,9$ $\mu \mathrm{mol} / 5.10^{5}$ cells) (Fig. 1).

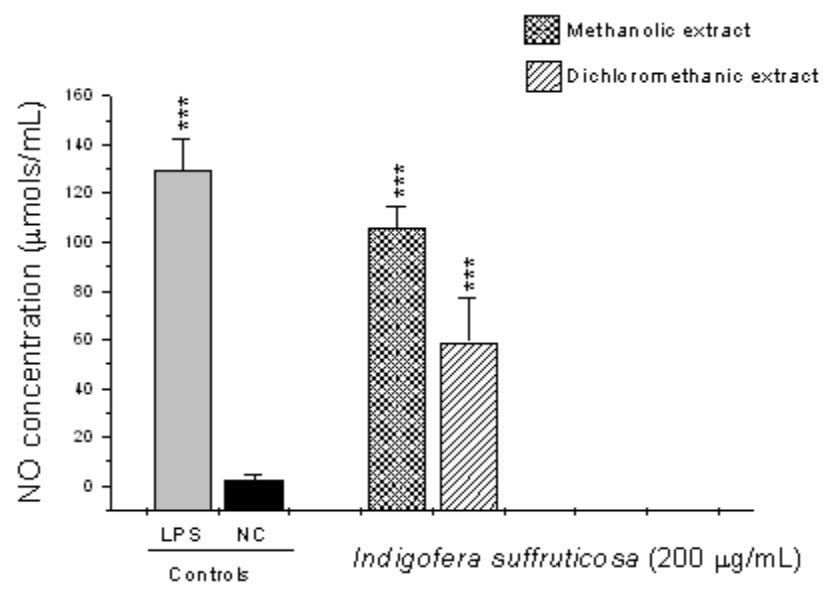

Fig. 1. Induction of nitric oxide.

The results regarding of TNF- $\alpha$ confirmed a significant production of this cytokine at levels near the positive control (252,7 and 234,6 units/mL, METH and DCM extracts, respectively) confirming a correlation between the synthesis of TNF-a and NO (Fig. 3) (Bogdan et al., 1991; Carli et al., 2009). 


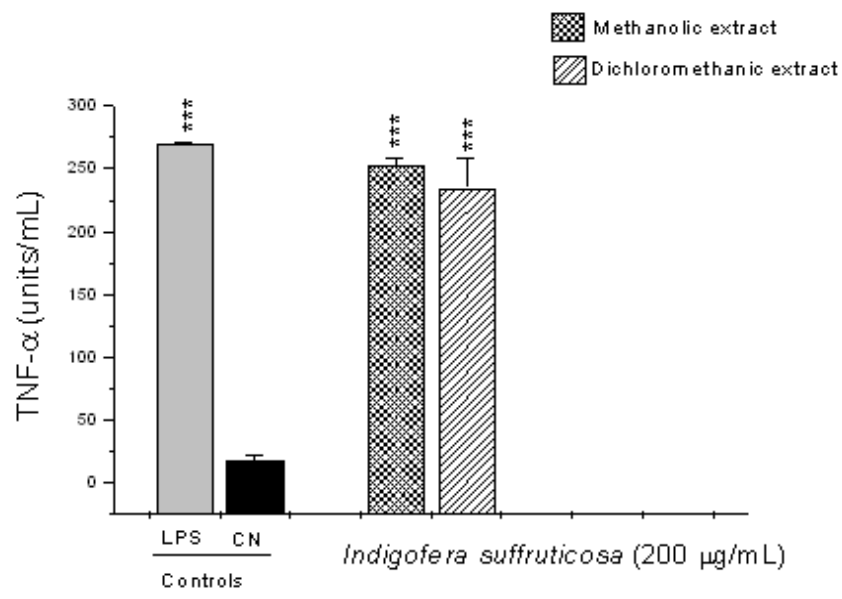

Fig. 2. Induction of tumor necrosis factor-a.

I. suffruticosa did not produce significant amounts of $\mathrm{H}_{2} \mathrm{O}_{2}$ when compared with control negative ( $p>0,05)$, METH (0,59 nmols/2.105cells) and DCM (3,3 nmols/2.105cells) (Fig. 3). This fact can be justified by the presence of tannins, such as gallic acid in extracts of $I$. suffruticosa. This class of substances has been showed an antioxidant potential being responsible for the scavenger of free radicals such as hydrogen peroxide. (Akira et al., 2002).

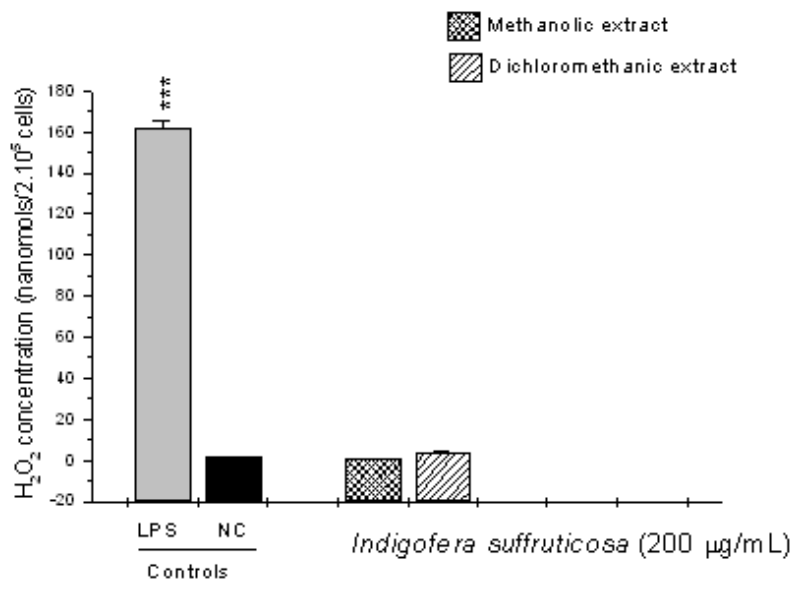

Fig. 3. Induction of hydrogen peroxide.

Thus, this screening suggests that both extracts of the I. suffruticosa promoted the activation of the macrophages. The significant production of studied mediators (NO and TNF- $\mathrm{a}$ ) by activated macrophages in presence of I. suffruticosa is very important, since macrophages produces several effector molecules that can enhance or restore the ability of the innate immune system to fight against TB infection. 
Nitric oxide (NO) formed by the action of the inducible form of nitric oxide synthase (iNOS) reacts with oxygen radical forming RNI. NO and related RNI have been reported to possess antimycobacterial activity (Kwon, 1997). Phagocytes kill intracellular organisms during an initial oxidative phase dependent on NADPH oxidase followed by a prolonged nitrosative phase during which bacterial growth is inhibited by iNOS (Nathan \& Shiloh, 2000). There are several potential mechanisms that can explain how NO may affect microbial life-cycle. NO and other RNI can modify bacterial DNA, protein and lipids at both the microbial surface and intracellularly. They can alter cytokine production and induce or prevent apoptosis of host cells by controlling caspase activity (Raupach \& Kaufmann, 2001).

M. tuberculosis strongly induces the release of several cytokines during infection. Tumor necrosis factor- $\alpha$ (TNF- $\alpha$ ) is a cytokine that plays multiple roles in immune and pathologic responses in tuberculosis, also required for acute infection control (Flynn et al., 1995). It plays a major role in the recruitment of inflammatory cells to the site of infection and in the formation and maintenance of granulomas (Gaemperli et al., 2006). This cytokine is necessary for optimal co-ordination of both the differentiation of specific $\mathrm{T}$ cells to secrete the appropriate $\mathrm{T}$ helper 1 cytokines and the development of granulomas in which activated macrophages restrict mycobacterial growth (Ehlers, 2003). TNF-a is required for control of latent TB and it is also a key element for activating macrophages to produce iNOS and thus in maintaining the pathway for generating NO and preventing reactivation of the disease (Adams et al., 1995).

\section{Conclusion}

We suggest that the extract may be an important bactericidal source against $M$. tuberculosis once the same has natural origin and do not present the toxic effects provoked by the drugs current used in the treatment of tuberculosis. Moreover, a possible association with traditional drugs can be suggested considering that the most of standard drugs do not present the same simultaneous effect microbiological and immunological of the extract here tested. These results described here highlight the importance of conducting an in-depth study of the species of the Brazilian biome, and show the great potential of it's biodiversity in the treatment of infection diseases.

\section{Acknowledgements}

The authors thank FAPESP for its financial support.

\section{References}

Adams, L.B.; Mason, C.M.; Kolls, J.K.; Scollard, D.; Krahenbuhl, J.L. \& Nelson, S. (1995). Exacerbation of acute and chronic murine tuberculosis by administration of a tumor necrosis factor receptor- expressing adenovirus. Journal of Infectious Diseases, Vol. 171, No.2, pp. 400-405, ISSN 00221899.

Akira, N.; Yuto, U.; Kunihiko, T. \&, Keisuke, M. (2002). Effect of tannin compounds on uranium-hydrogen peroxide system. Nippon Kagakkai Koen Yokoshu, Vol. 81, No. 1, pp.634, ISSN0285-7626. 
Algood, H. M.; Lin, P. L. \& Flynn,J. L. (2005). Tumor necrosis factor and chemokine interactions in the formation and maintenance of granulomas in tuberculosis. Clinical Infectious Diseases, Vol. 41, Suppl. 3, pp. S189-S193, ISSN1537-6591.

Allavena, P.; Sica, A.; Solinas, G.; Porta, C. \& Mantovani, A. (2008). The inflammatory microenvironment in tumor progression: the role of tumor-associated macrophages. Critical Reviews in Oncology/Hematology. Vol. 66, No. 1, pp. 1-9, ISSN1040-8428.

Barrar, N. R. A. \& Casero, J. (2006). Tumor necrosis factor-alpha increases reactive oxygen species by inducing spermine oxidase in human lung epithelial cells: a potential mechanism for inflammation-induced carcinogenesis. Cancer Research, Vol. 66, No. 23, pp. 11125-11130, ISSN1538-7445.

Bean, A.; Roach, D.; Briscoe, H.; France, M.; Korner, H.; Sedgwick, J. \& Britton, W. (1999). Structural deficiencies in granuloma formation in TNF gene targeted mice underlie the heightened susceptibility to aerosol Mycobacterium tuberculosis infection, which is not compensated for by lymphotoxin. Journal of Immunology, Vol.162, No. 6, pp. 3504-3511, ISSN1550-6606.

Bekker, L. G.; Freeman, S.; Murray, P. J.; Ryffel, B. \& Kaplan G. (2001). TNF-alpha controls intracellular mycobacterial growth by both inducible nitric oxide synthasedependent and inducible nitric oxide synthase-independent pathways. Journal of Immunology, Vol.166, No. 11, pp. 6728-6734, ISSN1550-6606.

Bogdan, C.; Vodovotz, Y. \& Nathan, C. (1991). Macrophage deactivation by interleukin 10. The Journal of Experimental Medicine, Vol. 174, No. 6, pp.1549-1555, ISSN1540-9538.

Brady, S.F. \& Clardy, J. (2000). CR377, a new pentakide antifungal agent isolated from an endophytic fungus. Journal of Naural Products, Vol. 63, No. 10, pp.1447-1448, ISSN1520-6025.

Cantrell, C.L.; Franzblau, S.G. \& Fischer, N.H. (2001). Antimycobacterialplant terpenoids. Planta Medica, Vol. 67, No. 1, pp1-10, ISSN1439-0221 .

Cardoso, S.R.A. (2006). Efeitos in vivo e in vitro da lectina de Synadenium carinatum sobre a infecção murina por Leishmania amazonensis,Uberlandia, Minas Gerais, Brasil.

Carli, C. B. A.; Matos, D. C.; Lopes, F. C. M.; Maia, D. C. G.; Dias, M. B.; Sannomiya, M.; Rodrigues, C. M.; Andreo, M. A.; Vilegas, W.; Colombo, L. L. \& Carlos, I. Z. (2009). Isolated Flavonoids against Mammary Tumour Cells LM2. Zeitschrift für Naturforschung, Vol. 67, No. 1, pp. 32-36, ISSN0932-0784.

Carlos, I.Z.; Sgarbi, D.B.G.; Angluster, J.; Alviano, C.S. \& Silva, C.L. (1994). Disturbances in the production of interleukin-1-necrosis and tumor necrosis factor in disseminated murine sporotrichosis. Mycopathologia, Vol. 127, No.3 , pp. 189-194, ISSN1573-0832.

Carlos, I. Z.; Monnazzi, L. G. S.; Falcão, D. P.\& De Medeiros, B. M. M. (2004). TNF , H2O2 and NO response of peritoneal macrophages to Yersinia enterocolitica O:3 derivatives. Clinical Microbiology and Infection, Vol. 174, No. 6, pp. 207-212, ISSN1469-0691.

Carlos, I. Z. ; Sassá, M.F. ; Placeres, M.C.P. ; Maia, D.C.G. (2009). Current research on the immune response to experimental sporothrichosis. Mycopathologia, Vol. 168, pp. 110, ISSN1573-0832.

Chan, E.D.; Chan, J. \& Schluger, N. W. (2001). What is the role of nitric oxide in murine and human host defense against tuberculosis? American Journal of Respiratory Cell and Molecular Biology, Vol. 25, No. 5, pp. 606-612, ISSN1535-4989. 
Chan, J.; Xing, Y.; Magliozzo, R. S.; \& Bloom, B. R. (1992). Killing of virulent Mycobacterium tuberculosis by reactive nitrogen intermediates produced by activated murine macrophages. Journal of Experimental Medicine., Vol. 175, No. 4, pp. 1111-1122, doi:10.1084/jem.175.4.1111 .

Chang HM, But PPH. (1986). Pharmacology and Applications of Chinese Materia Medica vol 1. World Scientific Inc., ISBN 9810236948, Singapore.

Cheel, J.; Antwerpen, P.V.; Tumová, L.; Onofre, G.; Vokurková, D.; Zouaoui-Boudjeltia, K.; Vanhaeverbeek, M. \& Nève, J. (2010) Free radical-scavenging, antioxidant and immunostimulating effects of a licorice infusion (Glycyrrhiza glabra L.). Food Chemistry, Vol. 122, No. 3, pp. 508-517, doi:10.1016/j.foodchem.2010.02.060.

Collins, L.S. \& Franzblau, S.G. (1997). Microplate alamar blue assay versus BACTEC 460 system for high-throughput screening of compounds against Mycobacterium tuberculosis and Mycobacterium avium. Antimicrobial Agents and Chemotherapy, Vol. 41, No. , pp. 1004-1009, ISSN1098-6596.

Copp, B.R. (2003). Antimycobacterial natural products. Natural Product Reports, Vol.20, No. 6, pp. 535-557 doi:10.1039/B212154A.

Ehlers, S. (2003). Role of tumour necrosis factor (TNF) in host defence against tuberculosis: implications for immunotherapies targeting TNF. Annals of the Rheumatic Diseases, Vol.62, Suppl. 2, pp. ii37-ii42, ISSN1468-2060.

Firmani, M. A. \& Riley, L. W. (2002). Reactive nitrogen intermediates have a bacteriostatic effect on Mycobacterium tuberculosis in vitro. Journal of Clinical Microbiology, Vol. 40, No. 9, pp. 3162-3166, doi:10.1128/JCM.40.9.3162-3166.2002.

Flesch, I. \& Kaufmann, S.(1987). Mycobacterial growth inhibition by interferon- _-activated bone marrow macrophages and differential susceptibility among strains of Mycobacterium tuberculosis. Journal of Immunology, Vol. 138, No. 12, pp. 4408-4413, ISSN1550-6606.

Flesch, I. E. \& Kaufmann, S. H. (1990). Activation of tuberculostatic macrophage functions by interferon, interleukin-4, and tumor necrosis factor. Infection $\mathcal{E}$ Immunity, Vol. 58, No. 8, pp. 2675-2677, ISSN1098-5522 .

Flynn, J.L.; Goldstein, M.M.; Chan, J.; Triebold, K.J.; Pfeffer, K.; Lowenstein, C.J.; Schreiber, R.; Mak, T.W. \&, Bloom, B.R. (1995). Tumor necrosis factor-a is required in the protective immune response against $\mathrm{M}$. tuberculosis in mice. Immunity, Vol. 2, No. 6, pp. 561-572, ISSN10747-613.

Franzblav SG, Cross CJ.(1986). Comparative in vitro antimicrobial activity of Chinese medicinal herbs. Journal of Ethnopharmacology,Vol. 15, No. 3, pp. 279-288, ISSN18727573.

Gaemperli, A. Hauser, T. \& Speck, R.F. (2006). Risk of infection during treatment with tumor necrosis factor-alpha inhibitors. Zeitschrift fur Rheumatologie, Vol. 65, No. 1, pp. 2431, doi:10.1007/s00393-005-0018-z.

Green, L.C.; Wagner, D.A.; Glogowski, J.; Skipper, P.L.; Wishnok, J.S. \& Tannenbaum, S.R. (1982). Analysis of nitrate, nitrite, and [15N] nitrate in biological fluids. Analytical Biochemistry, Vol. 126, No. 1, pp.131-138, ISSN1096-0309 .

Gu, J.Q.; Wang, Y.; Franzblau, S.G.; Montenegro, G.; Yang, D. \& Timmermann, B.N. (2004). Antitubercular constituents of Valeriana laxiflora. Planta Medica, Vol. 70, No. 6, pp.509-514, ISSN1439-0221. 
Gupta, R.; Thakur, B.; Singh, P.; Singh, H.B.; Sharma, V.D.; Katoch, V.M. \& Chauhan, S.V.S. (2010). Anti-tuberculosis activity of selected medicinal plants against multi-drug resistant Mycobacterium tuberculosis isolates. Indian Journal of Medical Research, Vol. 131, pp. 809-813, ISSN0971-5916.

Heldt, H. W. (1997). Pflanzenbiochemie. Heidelberg: Spektrum Akademischer Verlag, ISBN 978-3-8274-1800-5, Berlim, Germany.

Higuchi, C.T.; Pavan, F.R.; Sannomiya, M.; Vilegas, W. Leite, S.R.A.; Sacramento, L.V.S.; Sato, D.N. \& Leite, C.Q.F. (2008). Triterpenes and antitubercular activity of Byrsonima crassa. Quimica Nova, Vol. 31, No. 7, pp.1719-1721, ISSN0100-4042.

Higuchi, C.T.; Sannomiya, M.; Pavan, F.R.; Leite, S.R.A.; Sato, D.N.; Franzblau, S.G.; Sacramento, L.V.S.; Vilegas, W. \& Leite, C.Q.F. (2008). Byrsonima fagifolia Niedenzu apolar compound with antitubercular activity. Complementary and Alternative Medicine, doi:10.1093/ecam/nen077

Hinou, J.B.; Harvala, C.E.; Hinou, E.B. (1989). Antimicrobial activity screening of 32 commos constituents of essential oils. Pharmazie, Vol. 44, No. 4, pp.302-303, ISSN0031-7144 .

Huang, K.C. (1993). The Pharmacology of Chinese herbs, CRC Press, ISBN 9780849316654, Kentucky, USA.

Keane, J., Gershon, S.; Wise, R. P.; Mirabile-Levens, E.; Kasznica, J.; Schwieterman, W. D.; Siegel, J. N. \& Braun, M. M. (2001). Tuberculosis associated with infliximab, a tumor necrosis factor- alpha neutralizing agent. New England Journal of Medicine, Vol. 345, No. 15, pp. 1098-1104, ISSN1533-4406.

Keane, J.; Balcewicz-Sablinska, M. K; Remold, H. G.; Chupp, G. L ; Meek, B. B.; Fenton, M. J. \& Kornfeld, H. (1997). Infection by Mycobacterium tuberculosis promotes human alveolar macrophage apoptosis. Infection E Immunity, Vol. 65, No. 1 , pp. 298-304, ISSN1098-5522.

Keil, D.E.; Luebke, R.W. \& Pruett, B.S. (1999). Differences in the effects of dexamethasone on macrophage nitrite production: Dependence on exposure regimem (in vivo or in vitro) and activation stimuli. International Journal of Immunopharmacology, Vol. 17, No. 3 , pp.157-166, ISSN 0192-0561.

Kwon, O.J. (1997). The role of nitric oxide in the immune response of tuberculosis. Journal of Korean Medical Science, Vol. 12, No. 6, pp. 481-487, ISSN1598-6357.

Laster, S. M.; Wood, J. G. \& Gooding, L. R. (1988). Tumor necrosis factor can induce both apoptic and necrotic forms of cell lysis. Journal of Immunology, Vol. 141, No. 8, pp.2629-2634, ISSN1550-6606.

Lawal, T.O.; Adeniyi, B. A.; Wan, B.; Franzblau, S.G. \& Mahyad, G.B. (2011). In-vitro susceptibility of mycobacterium tuberculosis to extracts of Uvaria afzelli Scott elliot and Tetracera alnifolia willd african. Journal of Biomedical Research, Vol. 14, No. 1, pp.265-272, ISSN1674-8301 .

Leite, C.Q.F.; Moreira, R.R.D. \& Jorge-Neto, J.(1998). Action of Eucaliptus oils against Mycobactrieum avium . Fitoterapia, Vol.1, No.2, pp.282-3, ISSN1808-4532.

Lopes, F. C. M.; Benzatti, F. P.; Jordão-Junior, C. M.; Moreira, R. R. D. \& Carlos, I. Z. (2005). Effect of the essential oil of Achillea millefolium L. in the production of hydrogen peroxide and tumor necrosis factor- $\alpha$ in murine macrophages. Brazilian $J$ of Pharmaceutical Sciences, Vol.41, No.3 , pp. 401-405, ISSN 15169332. 
Lopes F C M, Calvo T R, Vilegas W, Carlos I.(2006) Indigotin alkaloid obtained from Indigofera suffruticosa Miller induces $\mathrm{NO}$ and TNF-a production by murine macrophages. Proceedings of the XXXI Meeting of the Brazilian Society of Immunology- Signaling in the Immune System, Buzios, RJ, Brazil, October 2006.

Marino, S., Sud, D.; Plessner, H.; Lin, P. L.; Chan, J.; Flynn, J. L. \& Kirschner, D. E. (2007). Differences in reactivation of tuberculosis induced from anti-TNF treatments are based on bioavailability in granulomatous tissue. PLoS Computational Biology,Vol.3, No. 10, pp. 1909-1924, ISSN 1553-7358.

McKinney, J.D. (2000). In vivo veritas: The search for TB drug targets goes live. Nature Medicine, Vol. 6, pp.1330-1333, doi:10.1038/82142.

Miyamoto, K.; Nomura, M.; Sasacura, M.; Matsui, E.; Koshiura, R.; Murayama, T.; Furucawa, T.; Hatano T, Yoshida, T. \& Okuda, T. (1993). Antitumor activity of oenothein B, a unique macrocyclic ellagitannin. Japanese Journal of Cancer Research ,Vol. 84, No.1, pp.99-103, ISSN0910-5050 .

Mohan, V. P.; Scanga, C. A.; Yu, K.; Scott, H. M.; Tanaka, K. E.; Tsang, E.; Tsai, M. M.; Flynn, J. L. \& Chan, J. (2001). Effects of tumor necrosis factor on host immune response in chronic persistent tuberculosis: possible role for limiting pathology. Infection and Immunity, Vol.69, No. 3, pp. 1847-1855, ISSN1098-5522.

Mosmann, T. (1983). Rapid colorimetric assay for cellular growth and survival: Application to proliferation and cytotoxicity assays. Journal of Immunology Methods, Vol. 65, No. 16 , pp. 55-63, ISSN0022-1759.

NAPRALER In: Natural Products Alert, Illinois University, Chicago. 2003. Accessed at http://www.uic.edu/phamacy/depts/PCRPS/ NAPRALERT.htm.

Nathan, C. \& Shiloh, M. U. (2000). Reactive oxygen and nitrogen intermediates in the relationship between mammalian hosts and microbial pathogens. Proceedings of the National Academy of Sciences of the United States of America, Vol.97, No. 16, pp. 88418848, ISSN1091-6490.

Nathan, C. \& Shiloh, M.U. (2000). Reactive oxygen and nitrogen intermediates in the relationship between mammalian hosts and microbial pathogens. Proceedings of the National Academy of Sciences of the United States of America, Vol. 97, No. 16, pp. 88418848, ISSN1091-6490 .

Nathan, C. (2002). Inducible nitric oxide synthase in the tuberculous human lung. American Journal of Respiratory and Critical Care Medicine,Vol. 166, No. 2, pp.130-131, ISSN1535-4970.

Okunade, A.L.; Elvin-Lewis, M.P. \& Lewis, W.H. (2004). Natural antimycobacterial metabolites: current status. Phytochemistry, Vol. 65, No. 8 , pp. 1017-1032, ISSN00319422.

Ouellet, H., Ouellet, Y., Richard, C., Labarre, M., Wittenberg, B., Wittenberg, J., and Guertin, M. (2002). Truncated hemoglobin $\mathrm{HbN}$ protects Mycobacterium bovis from nitric oxide. Proceedings of the National Academy of Sciences of the United States of America, Vol. 99, No. 9, pp.5902-5907, ISSN1540-9538.

Paiva, M.A.S.; Barbosa, A.C.D. \& Alves, H.L.J. (1987). Indigofera suffruticosa Mill (Leguminosae) com potencial forrageiro em uma região de Caatinga no Semi-árido de Pernambuco. (Alagoinha). Proceedings of the XXXVIII Congresso Nacional de Botânica. São Paulo, Brasil: Sociedade Nacional de Botânica. 
Palladino, M. A.; Bahjat, F. R.; Theodorakis, E. A. \& Moldawer, L. L. (2003). Anti TNF-a therapies: the next generation. Nature Reviews Drug Discovery, Vol. 2, No. 9, pp.736746, ISSN1474-1784.

Pavan, F.R.; Leite, C.Q.F.; Coelho, R.G.; Coutinho, I.D.; Honda, N.K.; Cardoso, C.A.L.; Vilegas, W.; Leite, S.R.A. \& Sato, D.N. (2009). Evaluation of anti-Mycobacterium tuberculosis activity of Campomanesia adamantium (MYRTACEAE). Quimica Nova, Vol. 32, No. 5, pp. 1222-1226, ISSN0100-4042.

Pick, E \& Keisare, Y. (1980). Superoxide anion and hydrogen peroxide production by chemically elicited peritoneal macrophages induction by multiple nonphagocytic stimuli. Cellular Immunology, Vol. 59, No. 2, pp.301-3118, ISSN1090-2163.

Pietro, R.C.L.R.; Kashima, S.; Sato, D. N.; Januário, A.H. \& França, S.C. (2000). In vitro antimycobacterial activities of Physalis angulate L. Phytomedicine, Vol.7, No. 4, pp.335-338, ISSN1618-095X.

Raupach, B. \& Kaufmann, S.H.E. (2001). Immune responses to intracellular bacteria. Current opinion in mmunology, Vol.13, No. 4, pp. 417-428, ISSN0952-7915.

Roach, D.; Bean, A.; Demangel, C.; France, M.; Briscoe, H. \& Britton, W. (2002). TNF regulates chemokine induction essential for cell recruitment, granuloma formation, and clearance of mycobacterial infection. Journal of Immunology,Vol. 168, No. 9, pp. 4620-4627, ISSN1550-6606.

Rook, G. A.; Steele, J.; Ainsworth, M. \& Champion, B. R. (1986). Activation of macrophages to inhibit proliferation of Mycobacterium tuberculosis: comparison of the effects of recombinant _-interferon on human monocytes and murine peritoneal macrophages. Immunology Vol. 59, No. 3, pp. 333-338, ISSN1365-2567.

Shiloh, M. U. \& Nathan, C. F. (2000). Reactive nitrogen intermediates and the pathogenesis of Salmonella and mycobacteria. Current Opinion in Microbiology, Vol. 3, No. 1, pp. 3542, ISSN1879-0364.

Stein, J. \& Nombela-Arrieta, C. (2005). Chemokine control of lymphocyte trafficking: a general overview. Immunology, Vol. 116, No. 1, pp 1-12, ISSN1365-2567 .

Tan, R.X. \& Zou, W.X. (2001). Endophytes: a rich search of functional metabólites. Natural Product Reports, Vol. 18, No. 4, pp.448-459, ISSN1460-4752 .

Van Buul, J. \& Hordijk, P. (2004). Signaling in leukocyte transendothelial migration. Arterioscler. Thromb. Vasc. Biol. Vol. 24, No. 5, pp. 824-833, ISSN1524-4636.

Voskuil, M. I.; Schnappinger, D.; Visconti, K. C.; Harrell, M. I.; Dolganov, G. M.; Sherman, D. R.; \& Schoolnik, G. K. (2003). Inhibition of respiration by nitric oxide induces a Mycobacterium tuberculosis dormancy program. Journal of Experimental Medicine, Vol. 198, no. 5, pp. 705-713, ISSN1540-9538.

Voskuil1, M. I.; Bartek, I.L.; Visconti, K \& Schoolnik, G. K. (2011).The response of Mycobacterium tuberculosis to reactive oxygen and nitrogen species. Frontier in Microbiology, Vol. 2, No. 105, doi: 10.3389/fmicb.2011.00105.

Walker, L. \& Lowrie, D.B. (1981). Killing of Mycobacterium microti by immunologically activated macrophages. Nature, Vol. 293, pp. 69-70, doi:10.1038/293069a0.

Who.int [http://www.who.int/tb/publications/global_report/2008/chapter_1/en/index3. html]. World Health Organization [updated 2008; cited 2008 December 3, Available from: http://www.who.int. 
Winthrop, K. L. (2006). Risk and prevention of tuberculosis and other serious opportunistic infections associated with the inhibition of tumor necrosis factor. Nature Reviews Rheumatology,Vol. 2, No. 11, pp. 602-610, ISSN1745-8390.

Yang, C. S.; Yuk, J. M.; \& Jo, E. K. (2009). The role of nitric oxide in mycobacterial infections. Immune Network Vol. 9, No. 2, pp. 46-52, ISSN 2092-6685.

Yee, D.; Valiquette, C.; Pelletier, M.; Parisien, I.; Rocher, I. \& Menzies, D. (2003). Incidence of serious side effects from first-line antituberculosis drugs among patients treated for active tuberculosis. American Journal of Respiratory and Critical Care Medicine, Vol. 167, No. , pp. 1472-1477, ISSN1535-4970.

Zhou, Z.; Connell, M. C. \& Macewan, D. J. (2007). TNFR1-induced NF-kappaB, but not ERK, p38MAPK or JNK activation, mediates TNF-induced ICAM-1 and VCAM-1 expression on endothelial cells. Cellular Signalling, Vol .19, No.6, pp. 1238-1248, ISSN1873-3913.

Zou, W.X.; Meng, J.C.; Lu, H.; Chen, G.X.; Shi, G.X.; Zhang, T.Y. \& Tan, R. X. (2000). Metabolites of Colletotrichum gloeosporioides, an endophytic fungus in Artemisia mongolica. Journal of Natural Products, Vol. 63, No. 11, pp.1529-1530, ISSN1520-6025. 


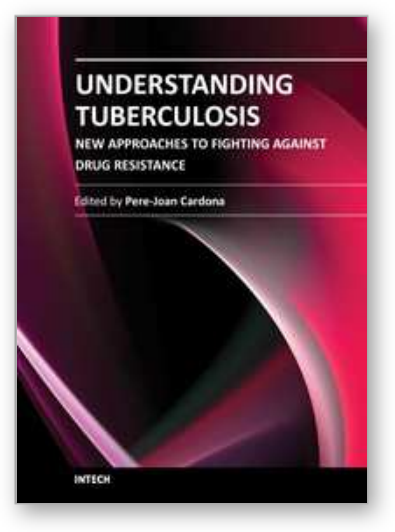

\author{
Understanding Tuberculosis - New Approaches to Fighting \\ Against Drug Resistance \\ Edited by Dr. Pere-Joan Cardona
}

ISBN 978-953-307-948-6

Hard cover, 376 pages

Publisher InTech

Published online 15, February, 2012

Published in print edition February, 2012

In 1957, a Streptomyces strain, the ME/83 (S.mediterranei), was isolated in the Lepetit Research Laboratories from a soil sample collected at a pine arboretum near Saint Raphael, France. This drug was the base for the chemotherapy with Streptomicine. The euphoria generated by the success of this regimen lead to the idea that TB eradication would be possible by the year 2000. Thus, any further drug development against TB was stopped. Unfortunately, the lack of an accurate administration of these drugs originated the irruption of the drug resistance in Mycobacterium tuberculosis. Once the global emergency was declared in 1993, seeking out new drugs became urgent. In this book, diverse authors focus on the development and the activity of the new drug families.

\title{
How to reference
}

In order to correctly reference this scholarly work, feel free to copy and paste the following:

Camila Bernardes de Andrade Carli, Marcela Bassi Quilles, Danielle Cardoso Geraldo Maia, Clarice Q. Fujimura Leite, Wagner Vilegas and Iracilda Z. Carlos (2012). Potential Use of I. suffruticosa in Treatment of Tuberculosis with Immune System Activation, Understanding Tuberculosis - New Approaches to Fighting Against Drug Resistance, Dr. Pere-Joan Cardona (Ed.), ISBN: 978-953-307-948-6, InTech, Available from: http://www.intechopen.com/books/understanding-tuberculosis-new-approaches-to-fighting-against-drugresistance/alternative-treatments-against-mycobacterium-tuberculosis

\section{INTECH}

open science | open minds

\section{InTech Europe}

University Campus STeP Ri

Slavka Krautzeka 83/A

51000 Rijeka, Croatia

Phone: +385 (51) 770447

Fax: +385 (51) 686166

www.intechopen.com

\section{InTech China}

Unit 405, Office Block, Hotel Equatorial Shanghai

No.65, Yan An Road (West), Shanghai, 200040, China

中国上海市延安西路65号上海国际贵都大饭店办公楼 405 单元

Phone: +86-21-62489820

Fax: $+86-21-62489821$ 
(C) 2012 The Author(s). Licensee IntechOpen. This is an open access article distributed under the terms of the Creative Commons Attribution 3.0 License, which permits unrestricted use, distribution, and reproduction in any medium, provided the original work is properly cited. 